concentrations closely similar to the range found in our present study. A conspicuous early ultrastructural feature of alcoholic liver damage is large, swollen mitochondria, suggesting that mitochondrial damage may be an important factor in the pathogenesis of alcoholic liver disease. Enzyme analysis of isolated hepatocyte mitochondrial fractions from patients with alcoholic steatosis, however, has failed to show evidence of mitochondrial damage." Concentrations of enzymes associated with mitochondrial membranes were unchanged but concentrations of enzymes in the mitochondrial matrix, including glutamate dehydrogenase, were significantly raised in alcoholic steatosis. This suggests that raised serum concentrations of glutamate dehydrogenase might be due to either hepatocyte damage or alcohol induction of liver mitochondrial enzyme activity.

Our study has therefore failed to confirm the usefulness of serum concentrations of glutamate dehydrogenase as an indicator of liver damage in patients with chronic alcoholism.

\section{References}

1 Van Waes L, Lieber CS. Glutamate dehydrogenase: a reliable marker of liver cell necrosis in the alcoholic. Br Med f 1977; ii :1508-10.

${ }^{2}$ Ellis G, Goldberg DM. Optimal conditions for the kinetic assay of serum glutamate dehydrogenase activity at 37 C. Clin Chem 1972;18:523-7.

${ }^{3}$ Lieber CS, Shaw S, Van Waes L. Alcoholism and alcoholic liver injury. Arch Pathol Lab Med 1978;102:393-5.

${ }^{4}$ Ellis G, Goldberg DM, Spooner RJ, Ward AM. Serum enzyme tests in diseases of the liver and biliary tree. Am F Clin Pathol 1978;70:248-58.

5 Jenkins WJ, Peters TJ. Mitochondrial enzyme activities in liver biopsies from patients with alcoholic liver disease. Gut 1978;19:341-4.

(Accepted 9 fuly 1981)

\title{
Dissemination of resistance plasmids among gentamicin-resistant enterobacteria from hospital patients
}

\author{
SIDONIE KNIGHT, MARK CASEWELL
}

\begin{abstract}
Out of 184 patients who were infected or colonised with gentamicin-resistant enterobacteria, $17(9 \%)$ harboured more than one strain. Single antibiotic-resistance plasmids were common to more than one of the different organisms isolated from nine patients, strongly suggestive of in-vivo conjugation. An "epidemic" plasmid with a molecular weight of approximately 110 megadaltons was found in 11 distinct strains isolated from four patients. Seven of the organisms harbouring this plasmid were Klebsiella aerogenes.

Spread of multiple-resistance plasmids among endemic gentamicin-resistant enterobacteria is not uncommon, and these organisms provide a reservoir of plasmids that may ultimately spread to more pathogenic genera.
\end{abstract}

\section{Introduction}

Interbacterial transfer of antibiotic-resistance plasmids by conjugation is a theoretically potent mechanism for limiting the clinical efficacy of many antimicrobial agents. Although the spread of plasmids from epidemic strains of multiply-resistant coliforms to other Gram-negative bacilli is recognised ${ }^{1-3}$ little is known about the frequency of plasmid spread among hospital bacteria during endemic colonisation and infection.

We therefore sought evidence for the spread of single plasmids among gentamicin-resistant enterobacteria isolated from patients in our hospital during a non-epidemic period.

\section{Patients and methods}

Between 20 February 1979 and 27 March 1980 we identified all inpatients at St Thomas's Hospital whose bacteriological specimens

\footnotetext{
Department of Microbiology, St Thomas's Hospital Medical School, London SE1 7EH

SIDONIE KNIGHT, BSC, research assistant

MARK CASEWEIL, MD, MRCPATH, senior lecturer in microbiology (now senior lecturer in medical microbiology, The London Hospital Medical College, London E1 2AD)
}

received by the diagnostic microbiology laboratory yielded more than one strain of gentamicin-resistant enterobacteria. Three strains from one patient at another hospital (case 9 ) were provided by D G White. Bacteria were identified by standard methods ${ }^{4}$ and controlled discdiffusion was used for sensitivity testing. ${ }^{5}$ Klebsiella capsular (K) typing was as described. ${ }^{6} 7$

Gentamicin-resistant enterobacteria from patients with more than one such strain were tested for plasmids that were transferable to Escherichia coli $\mathrm{K} 12 .{ }^{8}$ Transconjugants were tested for resistance to chloramphenicol $(\mathrm{Cm})$, tetracycline $(\mathrm{Tc})$, ampicillin $(\mathrm{Ap})$, carbenicillin $(\mathrm{Cb})$, cephaloridine (Cr), cephalothin (Kf), cephalexin (Cfx), cefuroxime, cefoxitin (Fox), sulphamethoxazole (Su), trimethoprim (Tp), streptomycin (Sm), kanamycin $(\mathrm{Km})$, neomycin $(\mathrm{Nm})$, gentamicin $(\mathrm{Gm})$, tobramycin $(\mathrm{Tm})$, amikacin, nitrofurantoin, and nalidixic acid. Plasmid molecular weights were determined by singlecolony lysate agarose-gel electrophoresis. ${ }^{9}$

\section{Results}

During the 13 months 184 patients at St Thomas's Hospital were found to have gentamicin-resistant enterobacteria; $17(9 \%)$ harboured more than one strain, and the isolates from 14 of these patients possessed plasmids that were transferable to $E$ coli K12. Eight of the St Thomas's Hospital patients with multiple strains of gentamicinresistant enterobacteria and the patient from another hospital were found to harbour two or more strains with common plasmids which were recognisable by their transferable resistance pattern and indistinguishable electrophoretic mobility. The table shows the resistance patterns and approximate molecular weights of these plasmids, together with the identification of their host bacteria and the clinical sources.

Klebsiella aerogenes was among the clinical isolates from eight of these patients and was the first gentamicin-resistant species isolated from seven patients. All but two of the patients had at least two distinct strains in their urine.

$K$ aerogenes $\mathrm{K} 21$, bearing a transferable plasmid of approximately 110 megadaltons which conferred the resistance pattern $\mathrm{ApCbCm}$ TcSuTpSmKmNmGmTm, was isolated from four patients; this plasmid was found in 11 epidemiologically distinct strains belonging to four different genera (see table).

\section{Discussion}

Our finding that as many as $9 \%$ of patients with clinical isolates of gentamicin-resistant enterobacteria were infected or colonised by more than one strain, and that almost half of these 
patients harboured several different strains or even different species bearing indistinguishable plasmids, indicates that considerable dissemination of plasmids does occur during periods of endemic colonisation and infection. Although plasmid transfer may have occurred between several enterobacteria before each patient acquired the strains, it seems more probable that our results reflect the transfer of plasmids from one strain to another after they were acquired by the patient-that is, by in-vivo conjugation.

In-vivo conjugation has been observed in the bowel of man, with $^{10}$ and without ${ }^{11}$ antibiotic selective pressure, and in the burns of mice. ${ }^{12}$ The frequency with which we have noted urinary isolates and the relative difficulties of achieving in-vivo conjugation in the human bowel ${ }^{13}$ suggest that the urinary bladder is a
-2 Markowitz SM, Veazey JM Jr, Macrina FL, Mayhall CG, Lamb VA. Sequential outbreaks of infection due to Klebsiella pneumoniae in a neonatal intensive care unit: implication of a conjugative $\mathrm{R}$ plasmid. f Infect Dis 1980;142:106-12.

3 Tompkins LS, Plorde JJ, Falkow S. Molecular analysis of R-factors from multiresistant nosocomial isolates. F Infect Dis 1980;141:625-36.

${ }^{4}$ Cowan ST. Cowan E Steel's manual for the identification of medical bacteria. Cambridge: Cambridge University Press, 1974.

${ }^{5}$ Bauer AW, Kirby WM, Sherris JC, Turck M. Antibiotic susceptibility testing by a standard single disk method. Am $\mathcal{f}$ Clin Pathol 1966;45: 493-6.

6 Casewell MW. Experiences in the use of commercial antisera for the capsular typing of Klebsiella species. 7 Clin Pathol 1972;25:734-7.

${ }^{7}$ Casewell MW. Titres and cross reactions of commercial antisera for the capsular typing of Klebsiella species. f Clin Pathol 1975;28:33-6.

${ }^{8}$ Coetzee JN, Datta N, Hedges RW. R-factors from Proteus rettgeri. f Gen Microbiol 1972;72:543-52.

Patients harbouring several gentamicin-resistant enterobacteria with plasmids common to more than one strain

\begin{tabular}{|c|c|c|c|c|c|}
\hline \multirow[b]{2}{*}{$\begin{array}{l}\text { Case } \\
\text { No }\end{array}$} & \multicolumn{3}{|c|}{ Clinical isolates } & \multicolumn{2}{|l|}{ Plasmid } \\
\hline & Date & Site & Organism & $\begin{array}{l}\text { Resistances } \\
\text { transferred }+\end{array}$ & $\begin{array}{l}\text { Molecular } \\
\text { weight } \\
\text { (mega- } \\
\text { daltons) }\end{array}$ \\
\hline 1\{ & 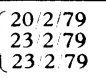 & $\begin{array}{l}\text { Blood } \\
\text { Urine } \\
\text { Urine }\end{array}$ & $\begin{array}{l}K \text { aerogenes } \mathrm{K} 21 \\
K \text { aerogenes } \mathrm{NT} \\
E \text { coli }\end{array}$ & ApCbCmTcSuTpSmKmNmGmTm & 110 \\
\hline 2\{ & $\begin{array}{l}145 / 79 \\
16 / 5 / 79\end{array}$ & $\begin{array}{l}\text { Urine } \\
\text { Faeces }\end{array}$ & $\begin{array}{l}K \text { aerogenes } \mathrm{K} 21 \\
E \text { coli }\end{array}$ & ApCbCmTcSuTpSmKmNmGmTm & 110 \\
\hline 3\{ & $\begin{array}{l}21 / 679 \\
197779 \\
20779\end{array}$ & $\begin{array}{l}\text { Ulcer } \\
\text { Faeces } \\
\text { Wound }\end{array}$ & $\begin{array}{l}K \text { aerogenes } \mathrm{K} 21 \\
E \text { coli } \\
E \text { cloacae }\end{array}$ & ApCbCmTcSuTpSmKmNmGmTm & 110 \\
\hline 4 & $\begin{array}{r}37779 \\
37779 \\
47779 \\
4779 \\
27779\end{array}$ & $\begin{array}{l}\text { Wound } \\
\text { Wound } \\
\text { Urine } \\
\text { Urine } \\
\text { W'ound }\end{array}$ & $\begin{array}{l}K \text { aerogenes } \mathrm{K} 21 \\
K \text { aerogenes } \mathrm{K} 3 \\
C \text { freundii } \\
E \text { coli } \\
K \text { aerogenes } \mathrm{K} 64\end{array}$ & ApCbCmTcSuTpSmKmNmGmTm & 110 \\
\hline 5\{ & $\begin{array}{l}5979 \\
5979\end{array}$ & $\begin{array}{l}\text { Urine } \\
\text { Urine }\end{array}$ & $\begin{array}{l}K \text { aerogenes } \mathrm{K} 21 \\
K \text { aerogenes } \mathrm{K} 60\end{array}$ & ApCbCmTcTpGmTm & 105 \\
\hline 6\{ & $\begin{array}{r}98 / 79 \\
15879\end{array}$ & $\begin{array}{l}\text { Urine } \\
\text { Urine }\end{array}$ & $\begin{array}{l}E \text { coli } \\
K \text { aerogenes NT }\end{array}$ & ApCbCrCmTcSuTpSmKmNmGm & 57 \\
\hline 7\{ & $\begin{array}{l}23779 \\
23779\end{array}$ & $\begin{array}{l}\text { Urine } \\
\text { Urine }\end{array}$ & $\begin{array}{l}E \text { coli } \\
S \text { marcescens }\end{array}$ & ApCmSuTpKmNmGmTm & 80 \\
\hline 8\{ & 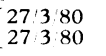 & $\begin{array}{l}\text { Urine } \\
\text { Urine }\end{array}$ & $\begin{array}{l}K \text { aerogenes } \mathrm{K} 16 \\
E \text { coli }\end{array}$ & ApCbCrKfCmTcSuTpSmKmNmGm & 62 \\
\hline $9 *\{$ & 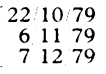 & $\begin{array}{l}\text { Urine } \\
\text { Urine } \\
\text { Urine }\end{array}$ & $\begin{array}{l}K \text { oxytoca } \mathrm{K} 43 \\
E \text { coli } \\
\text { Kaerogenes } \mathrm{K} 64\end{array}$ & ApCbCrKfCfxFoxCmTcSuTpGm & 50 \\
\hline
\end{tabular}

* Not a patient at St Thomas's Hospital.

+Ap, ampicillin. Cb, carbenicillin. Cm, chloramphenicol. Tc, tetracycline. Su, sulphamethoxazole. Tp, cephaloridine. Kf, cephalothin. Cfx, cephalexin. Fox, cefoxitin.

more likely anatomical site for conjugation between enterobacteria.

$K$ aerogenes $\mathrm{K} 21$, which is one of the more prevalent strains in Britain, ${ }^{14}$ was isolated from four patients in two small clusters of cross-infection, and for these patients it was the first isolate to be found with the plasmid of 110 megadaltons which was ultimately found in nine other strains of enterobacteria. Thus this plasmid seems to be already "epidemic" at St Thomas's Hospital.

Resistance genes from coliform-derived plasmids have already been implicated in ampicillin-resistant ${ }^{15}$ and chloramphenicolresistant ${ }^{16}$ Haemophilus influenzae, in penicillinase-producing Neisseria gonorrhoeae, ${ }^{17}$ and in carbenicillin-resistant Pseudomonas aeruginosa. ${ }^{18}$ The results of this study indicate that endemic gentamicin-resistant enterobacteria, especially Klebsiella spp, ${ }^{19}$ provide an abundant reservoir of transferable plasmids. In the absence of controlled antibiotic usage and epidemiological containment of these strains, it seems probable that resistance genes derived from these plasmids will increasingly disseminate among more pathogenic genera.

\section{References}

${ }^{1}$ Datta N, Hughes VM, Nugent ME, Richards H. Plasmids and transposons and their stability and mutability in bacteria isolated during an outbreak of hospital infection. Plasmid 1979;2:182-96.
${ }^{9}$ Eckhardt T. A rapid method for the identification of plasmid desoxyribonucleic acid in bacteria. Plasmid 1978;1:584-8.

10 Anderson JD, Gillespie WA, Richmond MH. Chemotherapy and antibiotic-resistance factor transfer between enterobacteria in the human gastro-intestinal tract. $f$ Med Microbiol 1973;6:461-73.

1 Smith HW. Transfer of antibiotic resistance from animal and human strains of Escherichia coli to resident $\mathrm{E}$ coli in the alimentary tract of man. Lancet 1969 ; : 1174-6.

1.2 Roe E, Jones RJ, Lowbury EJL. 'Transfer of antibiotic resistance between Pseudomonas aeruginosa, Escherichia coli, and other Gram-negative bacilli in burns. Lancet $1971 ;$ i :149-52.

${ }^{13}$ Wiedemann B. Resistance transfer in vivo and its inhibition. Krcmery V, Rosival L, Watanabe 'T, eds. Bacterial plasmids and antibiotic resistance. Berlin: Springer-Verlag, 1972:75-90.

14 Casewell MW, Talsania HG. Predominance of certain klebsiella capsular types in hospitals in the United Kingdom. Fournal of Infection 1979; 1 $77-9$

${ }^{15}$ Medeiros AA, O'Brien TO. Ampicillin-resistant Haemophilus influenzae type $B$ possessing a TEM-type $\beta$-lactamase but little permeability barrier to ampicillin. Lancet $1975 ; \mathrm{i}: 716-8$.

${ }^{16}$ Kattan S. Chloramphenicol-resistant haemophilus. Lancet 1976;i :814.,

17 Elwell LP, Roberts M, Mayer LW, Falkow S. Plasmid-mediated betalactamase production in Neisseria gonorrhoeac. Antimicrob Agents Chemother 1977;11:528-33.

1s Ingram LC, Richmond MH, Sykes RB. Molecular characterization of the $\mathrm{R}$ factors implicated in the carbenicillin resistance of a sequence of Pseudomonas aeruginosa strains isolated from burns. Antimicrob Agents Chemother 1973;3:279-88.

19 Casewell MW, Talsania HG, Knight S. Gentamicin-resistant Klebsiella aerogenes as a clinically-significant source of transferable antibiotic resistance. $\mathcal{f}$ Antimicrob Chemother (in press).

(Accepted 6 fuly 1981)

.

(2)

